Abstracta Iranica Abstracta Iranica

Revue bibliographique pour le domaine irano-aryen

Volume 32-33 | 2013

Comptes rendus des publications de 2009-2010

\title{
Emmanuel Fons. À propos des Mongols. Une lettre d'Ibn Taymiyya au sultan al-Malik al-Nāṣir Muhammad b. Qalāwūn
}

Denise Aigle

\section{(2) OpenEdition}

1 Journals

Édition électronique

URL : http://journals.openedition.org/abstractairanica/40600

DOI : 10.4000/abstractairanica.40600

ISSN : 1961-960X

\section{Éditeur :}

CNRS (UMR 7528 Mondes iraniens et indiens), Éditions de l'IFRI

\section{Édition imprimée}

Date de publication : 1 décembre 2013

ISSN : 0240-8910

\section{Référence électronique}

Denise Aigle, «Emmanuel Fons. À propos des Mongols. Une lettre d'Ibn Taymiyya au sultan al-Malik alNāṣir Muhammad b. Qalāwūn », Abstracta Iranica [En ligne], Volume 32-33 | 2013, document 224, mis en ligne le 01 juillet 2016, consulté le 27 septembre 2020. URL : http://journals.openedition.org/ abstractairanica/40600; DOI : https://doi.org/10.4000/abstractairanica.40600

Ce document a été généré automatiquement le 27 septembre 2020.

Tous droits réservés 
Emmanuel Fons. À propos des Mongols. Une lettre d'Ibn Taymiyya au sultan al-Malik al-Nāșir Muhammad b. Qalāwūn

Denise Aigle 


\section{RÉFÉRENCE}

Emmanuel Fons. « À propos des Mongols. Une lettre d'Ibn Taymiyya au sultan al-Malik al-Nāșir Muḥammad b. Qalāwūn ». Annales Islamologiques, vol. 43, 2009, p. 31-69, texte arabe, p. 74-69.

Dans cet article, E.F. a traduit, édité et commenté une lettre adressée par Ibn Taymiyya au sultan mamelouk, al-Malik al-Nāṣir Muhammad. Cette risāla est un document important pour la connaissance des événements qui se sont déroulés pendant les expéditions de Ġāzān Hुān en Syrie, entre 1299 et 1303, au même titre que les trois fatwas dites "anti-mongoles ». L'A., en recoupant les informations contenues dans la lettre avec les événements historiques, suppose qu'elle a été rédigée en jumādā I 700/ janv. 1301, au moment où Ibn Taymiyya se rendit au Caire pour pousser le sultan au djihad. On retrouve dans cette lettre la même argumentation pour dénoncer l'Islam des Ilkhans que dans ses trois fatwas. Afin de prouver l'infidélité des Mongols, le savant hanbalite les accuse d'accueillir dans leurs rangs des polythéistes, des gens du Livre (juifs, chrétiens et zoroastriens) et des hérétiques (jahmiyya, ittahādiyya, qādiriyya, bātiniyya). Il évoque également le cas de la Djézireh (dār al-ḥarb) : le nord-est de la Syrie est considéré comme une frontière militaire. Ibn Taymiyya veut convaincre le sultan mamelouk de la nécessité de déplacer le champ de bataille de la Syrie à l'Euphrate, et même en territoire ennemi.

\section{AUTEURS}

\section{DENISE AIGLE}

EPHE, Paris 